\title{
Treating 'Free Word Order' in Machine Translation
}

\author{
Ralf STEINBERGER \\ UMIST - Centre for Computational Linguistics \\ Manchester, UK, ralf(occl.umist.ac.ulk
}

\section{Abstract}

In free word order languages, every sentence: is embedded in its specific context. 'The order' of constituents is determined by the categories theme, rheme and contrastive focus. This paper shows how to recognise and to translates these ategories automatically on a sentential bass, so that sentence cmbedding can be achieved withont having to reter to the context. 'Traditionally neglected modifier' classes are fully covered by the proposed method.

\section{Introduction}

Most languages known as free word order languages are in fact languages with partially free word order (1ingelkarnp) of al. 1992), or rather free phrase order (Schäul'ele 1991). A dificulty linked to the formal description of these languages is that instead of a complete lack ol' ordering rules many subtle restrictions apply. A large amount of word order variations are grammatical in isolated sentences, but context restriets the number of secuences which are possible and natural. In this sense, sentences are embedded in their context. A spe.cific context calls for a certain word order, and the word order of a given sentence reflects its context.

In this paper, we present recent suggestions on how to treat free phrase order in Nat,ural Iranguage Processing (NI,l), and present an alternative solution to the problem. 'The idea is to use a thematically-lagyed, or flextble, canonical form (CF) for goneration, and an algorithm to recognise the relevant cat- cgories theme, theme and contrastive focus during analysis. 'This melhod has been inplemented succosslully in the unification and constraint-based Machine 'Translation system CA'T2 (Sharp 1989, Steinberger 1992a). Th, in chades the ordering of modifiers, which are traditionally lett ont in word order description (Conlon/livens 1992). All statements in this paper concen writben language, as spoken language is more liberal with respect to ordering.

\section{The Data}

We shall start by presenling some data which illustrates the problems related to word order traatment in Nl,P. Many ordering variabions are possible (1a-1e, 2a, 2b), but, some of them aro less natural (10), and others are even ungrammatical $(2 c, 2 d)$. Te is only acceplable if the personal pronoun ich is heavily stressed, indicated here in capitals.'

la Morgensti werde ich ilu vielkeicht. besuchen. T'omorrow will I him probably visil

Ib tch werde ihn vielle ichat 2 mergengh besuchen. I will him probably lomorrow visit

1c tch werde ihn morgen 26 vielleicht 12 besuchen. I will him lomorrow probably visit

a Viclkichli2. werde ich ihn morgengo besuchen. Probably will I him lomotrou visil

le? Morgeng2 werde ilun vielleichtit2 ICIl besuchen. 'Tomorrow will him probelly nisit

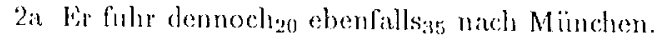
the drove neverthrless also to Munich

\footnotetext{
'The use of the index numbers will be explained in section 5 .
} 
2b Dennoch ${ }_{20}$ fuhr er ebenfalls $s_{35}$ nach München.

Nevertheless drove he also to Munich

2c * Er fuhr ebenfallsas dennoch 20 nach München.

He drove also nevertheless to Munich

2d * Ebenfalls 35 fuhr er dennoch ${ }_{20}$ nach München.

Also drove he nevertheless to Munich

Depending on the context, different word orders are either required or, at the very loast, they are more natural than others. Although in 3 and 4 the context is represented by cuestions, it is not normally limited to these. 3a, which is the most natural answer to 3 , is very unnatural, if not ungrammatical, in $4 . \mathrm{N}$ though not all contexts restrict the order of constituents as drastically as 3 and 4 , it is a general rule for German and similar languages that sentences are more natural il they are properly embedded in their contexts:

3 Wen erwartete die Frau mit dem Nudelholz? Whom waited-for the woman with the rolling pin

3a Die Frau erwartete mit dem Nudelholz ilıren MANN.

The woman waited-for wilh the rolling pin her husband

3b? Die Frau erwartete ilıren MANN mit dem Nudelholz.

The woman wated-for her husband with the rolling pin

1 Mit was erwartete die Fran ihren Mann? With-what wailed-for the woman her husband

4a Die Frau erwartete ihren Mann mit dem NUdelhol\%.

The woman waited-for her husband with the rolling pin

4b ?? Die Frau erwartete mit dem NUdelholy ilren Mann.

The woman waited-for with the rolling pin her husband

It is generally acknowledged that, the combination of several factors determines the order of constituents in German and similar languages. In Steinberger (1994), cleven principles acting on the pragmatic, semantic and syntactic levels are listed, each of which can be reformulated as one or several lincar precedence (LP) rules. The factors comprise of the tendencies to order elements according to the theme-rheme structure and/or to the functional sentence perspective. Turthermore, they concern verb bonding, animacy, heaviness, the importance of semantic roles for phrase ordering, and others. $\Lambda$ distinct feature of the ordering regularities is that none of the factors can be formulated as an absolute JP rule, which makes word order description difficult to deal with in NI.P. In recent, years several propositions were made to deal with this phenomenon in either analysis or generation, or both.

\section{Recent Suggestions on Treating Free Phrase Order}

Uszkoreit (1987) suggests overcoming the lack of absolute rules by using disjundtions of LP rules. The idea is that if at least one LP rule sanctions a sequence of constitucnts, the sentence is grammatical. The model thus expresses competence, rather than performance, as it either accepts or rejects a sentence, withoul making a judgement on acceptability differences as in 1.

Another idea put forward by Erbach (1993) accounts for grades of accoptability. Wrbach assumes that the order of verb complements icleally is according to an oblicpeness hierarchy, and that cach deviation from this order decreases the acceptability of the sentence by a factor of 0.8. 'T'wo divergences result in an acceptability score of $0.64(0.8 * 0.8)$, cte. Problems we see linked to this approach are the use of the obliqueness hicrarchy, which limits the preference mochanism to complements, and the fact that every diversion decreases the score invariably, without considering the varying effect of different variations.

$\Lambda$ proposal which takes into account tho different importance, or weight, of preference rules, is presented in Jacobs (1988). Jacobs assigns each of his prefcrence rules a specific numerical weight. If a rule applies in a given sentence, its value is added to the acceptability score of the sentence, if it is violated, its value is subtracted. 'The higher the final score, the more natural, or the 'better' the sentence is. 
Ideally, all competing preference rules are sat;isfied. The complication we see with this approach is that some strictly ordered sepuences interfere with the calculation of acceptability. Some of them concern the ordering of toners ( $\Lambda$ btönungspartikeln; 'Thurmair 1989) and other modifier subgroups (Steinberger 1994).

Some of the criticism could be overcome by changing the different propositions slightly. For instance, lirbach's (1993) suggestion to add preference to feature-based formalisms could be combined with Uszkoreit's prelorence rules. An idea to solve the problems linked to Jacobs' weighing mechanism would be to combine it with absolute l.P rules, in order to avoid ungrammatical sequences. However, wo want to suggest another method, based on our findings concorning natural, marked and ungrammatical word order, and making use of the categories theme, rheme and contrastive focus (hencelorth simply called focus).

\section{The New Model}

In our approach (ci. Stcinberger 1994), we have different, ways of dealing with free phrase order in analysis and generation. In analysis (cl. section 6), grammars have to allow most orderings, as barcly any phrase order can be completely excluded. Once a structure is atssigned to an input sentence, we suggest that thematic, rhematic and contrastively focussed elements be identified by using our insights concerning the recognition of these categories. 'l'his informalion concerning functional ser. tence perspective can and should be conveyed in the target language of the transtation.

With respect to generation (cf. section 5), acceptable orderings are defined by a sin. gle comprehensive linear precedence (T.P) rule which not only assigns strict priorilics to symbols tagged for syntactic category (e.g. N for nominative NP, SIT for situative complement, $M$ for modifier), but also for the thematic catcgories theme, rheme and contrastive focus. It is crucial that the relative ordering of synlactic symbols can be varied by varying their respective thematic markings. The I.P' rule also assigns prioritice to syntactic categorics which are not themalically marked. 'Thus, a syntaktic element is assigned a default position il no thematic information is available, but is moved out of this clefault position il thematic information is present. In this way, a single rule represents a fixed canonical form for unmarked elements and at the same time permits widely varying (though not truly free) orderings for thematically marked cases.

Gencration and analysis according to this method will be presented in more detail now.

\section{Generation}

We argue in Steinberger (1994) that lhe 11 se of a comprchensive lep rule, as presented in the previous section, is an efficient, way of gencrating sentences which not only are correct in some contexts but which comply with their contextual restrictions. 'This flexible output, is achieved by using the thee thematic categories theme, rheme and contrastive focus, which can capture complements as well as modifiers realised by all phrasial calegories. Thable 1 shows such a Cit: for German.

The table is to be read from left to right and from top to bottom. The lethers $\mathrm{N}, \Lambda$, D, (r represent the four cases nominative, accusalive, dative, and genitive. PO stands for prepositional object, and SIT, DIR and EXP for situative, directional and expansive complements. Nom and $\Lambda d j$ are nominal and adjectivat complements, $M$ represents lhe diverse groups of modifiers. 'The feabure +/-d relers to definiteness, t/-a lo animacy, SVO lo support, verb conslidedions, and the index numbers to $M$ indicate the relative order of modifiers $\left(M_{1}\right.$ precedes $\mathrm{M}_{2}$, and so on). The index numbers are based on Hoberg's classification (1981). Il clements cannot cooccur, they are separated by a slash (/), as opposed to by an arrow $(<)$.

The CH imposes linear order on an unordered set of arguments and modifiers. When the analysis of the soture language lats to recognise theme, rheme and focus, a defauld, oreler is generabed. Although no Cli sequence can produce good sentences in all contexts (el. 3 and 4 ), the default order is suitable in a large amount of contexts. 


$$
\begin{aligned}
& \mathrm{N}_{\text {pron }} / \mathrm{N}_{+d+b}<(\Lambda<\mathrm{D} / \mathrm{Nom} / \Lambda \mathrm{dj})_{\text {pron }}<\mathrm{THEME}<\mathrm{N}_{+\cdot d-a} / \mathrm{N}_{-a+a}< \\
& <\left(\mathrm{N}_{\text {pron }} / \mathrm{N}_{+d+a}\right)_{+f o c u s} /(\Lambda<\mathrm{D})_{\text {prontfocus }}<(\mathrm{A}<\mathrm{D})_{+d+a}<\mathrm{G}_{\text {prom }}<\mathrm{N}_{-d-a}<(\Lambda<\mathrm{D})_{+d-a}< \\
& <\mathrm{M}_{\text {pragm }(a 1-18)}<\mathrm{M}_{\text {sit(a19-40) }}<\mathrm{M}_{\text {ncog(41) }}<\mathrm{M}_{\text {modl(12-43) }}<
\end{aligned}
$$

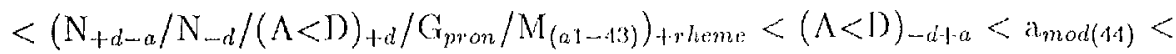

$$
\begin{aligned}
& <\mathrm{PO}_{\text {pron }}<(\Lambda<\mathrm{D})_{-d-a}<\mathrm{PO}_{+\cdot d+a}<\mathrm{PO}_{+d-a}<\mathrm{PO} \mathrm{O}_{-d+a}<\mathrm{PO}_{-d-a}<\mathrm{G}_{n a m}< \\
& <\left(\Lambda / \mathrm{D} / \mathrm{G} / \mathrm{PO} / \mathrm{N}_{+-d-a} / \mathrm{N}_{-d} / \mathrm{M}_{3, m a m} / \mathrm{M}_{\text {sit }} / \mathrm{M}_{\text {moll }}\right)_{+j o c u s}< \\
& <\mathrm{SIT} / \mathrm{DIR} / \mathrm{EXP}<(\mathrm{Nom} / \Lambda \mathrm{dj})_{- \text {pron }}<(\mathrm{N} / \mathrm{N} / \mathrm{D} / \mathrm{G} / \mathrm{PO})_{\text {SVC }}
\end{aligned}
$$

Table 1: 'Thematically-tagged' Canonical Form for German

Before showing some example sentences generated by this $\mathrm{CF}$, we have to mention one particularity of German, which is that the verb is in second position in declarative matrix clauses (verb-sccond, or V2 position), and in final position in subordinate clauses (verbfinal, or VF position). Nearly any element can take the one position preceding the verb in $\mathrm{V} 2$, called the Vorfeld ("pre-(verbal) field"). Nor'mally a thematic element is placed into the Vorfeld. According to Hoberg's (1981) analysis of the Mannheimer Duden Korpus, in 63\% of all V2 sentences the nominative complement. (subject) takes this place. A convenient, way of seeing it is that all elements follow the verb in $\mathrm{V} 2$ position according to the $\mathrm{CF}$, and that one (thematic) element is moved into the Vorfeld position. We suggest that if the analysis of the source language fails to recognise the theme of the sentence, the subject takes this place.

In our model, most elements can either be thematic, rhematic, or neulral (i.e. unmarked with respect to theme and rheme). Sentence variations as different as shown in the examples $5 \mathrm{a}$ to $5 \mathrm{~d}$ can be generated using the canonical form presented above, depending on the parameterisation of the features theme, rheme and focus for the different constituents. The order of elements in 5 a corresponds to the default order. However, the same order would be generated if the personal pronoun was marked as being thematic, and/or if the arlverb gestern was rhematic. We put the information theme in $5 \mathrm{a}$ to $5 \mathrm{c}$ in brackets to indicate that this
Feature is not a requirement, to generate the respective word orders. 'The relative order of the adverly and the accusative NP in 5b differs from the one in 5a, becallse lhe object den Mann is rhematic. In $5 \mathrm{c}$ and $5 \mathrm{~d}$, gestern and den Mann are thematic, respectively. In acldition to this, the personal pronoun in 50 is marked as being stressed contrastively. We used capitial letiers to express the obligatiory focus. It is easy to think of more phrase order combinations caused by further parametcrisations.

5a lch(theme) habe den Mann gestern $26(+r h e m e)$ gesehen. $\left(\Lambda_{+\mathrm{d}+a}-\mathrm{M}_{26}\right)$

I have the man yesterday seen

5b) Icls (theme) habe gesternog den Mann+rheme gesehen.

I have yesterday the man seen

5c Cesterngotheme habe ich den Mannirheme) gesehen.

Yesterday have I the man seen

5 d Den Mannfliene habe gesterngotheme $\mathrm{ICII}_{+j \text { veus gesehen. }}$

The man have yesterday I seen.

Modifiers should be classified according to IJoberg's (1981) 11 modifier position classes, which partly coincide with the common semantic classifications, and partly not. Hoberg's modifier indexes are the result of the stalistical verification of Engel's intuilive classes (1970). $\Lambda$ s modiliers do not always follow in the same order, Hoberg close a classification which lead to least deviations botween hor classification 
and the order in the corpus used (Mamnheimer Duden Korpus). The lollowing sentences exemplify the order of the CF for modifiers:

6a Ich habe deshalb 22 gestern 26 mit, Woll 4 2 fornge. sehen.

I have therefore yesterday with Wolf witched-to

6b Ich habe deshalb 22 mit Woll 42 gesternghtrheme ferngesehen.

I have therefore with Wolf yesterday walched-to

7 Damals $26+$ theme bin ich lirauen obnehing oft 37 überstïrths davongelaufen.

Then am I women anyway often overhastyly rithaway (Then, I oflen ran away from women overhastily anyway)

D) to the procedure described in this section, ungrammatical sentences such as $2 \mathrm{c}$ and 2d can be avoided successfully.

\section{Analysis}

The generation of contextually embedded sentences is based on the successful analysis of theme and rheme constituents. 'The recognition of contrastive stress is even more important. $\Lambda$ basic fact that can be used for the antomatic recognition of these categories is that not only the context determines the ordering of constituents in an embedded sentence, but also a given sentence carries information on the context to which it belongs. When German native speakers sec the sentence $3 a / 4 b$, for instance, they have a strong lecling aboul, the context in which it occurs. It is very likely that the NP itren Mann is stressed. It is cither rhematic, or it carries contrastive focus. Le is even more restricted. The personal pronoun $i c h$ must be contrastively stressed (l myself am the person who visits hirn). In every context requiring another stress, 1e is ungrammatical. $\mathrm{It}$ is thus possible to extract information on the context of a given sentence withoul having access to the preceding sentences.

Analysis grammars must allow most constituent order variations, as the number of phrase orders that can be excluded is very limited. The difference with generation grammars is that it is stufficient to generale one 'good' phrase order for each context, whereas in analysis all possible variations have to be allowed.
For this reason, the CF is of no use for anatysis. Instead, analysis grammars should allow all grammatical orders and identily thematic, rhematic and focussed phrases.

In our algorithm, the number of possible themes and rhemes is limited to one constituent cach, as this is sufficient lo generate the variations in 5 to 7 . lirstly, focus should be identified, and after this theme and rheme. Some permutations are only possible if one constituent is stressed contrastively. These constructions include the Vorfeld position of some typically rhematic elements $(8,9)$, the right, movement of constituents which have a strong tendency to the left (cl. 1e and $5 \mathrm{~d}$ above), and others (Stcinberger 1994).

8 Nach l'RANKreich+fous ist Vahe geflogen. To france is Vahé flew (Vahé flew to france)

9 Einen INder+focts hat Anne goheiratet.

An Indian has Anne married (Anue his married (tn Indian)

In the next step, the theme category is identified. livery element at the beginning of the clause is marked as a theme if it has not beon identified as a focus in the preceding step $(10,11)$ :

10 Damals theme lebte Hendrix noch. Then lived Ilendrix still (Ilendrix was still alive. then)

11 Ich glaube, daß linat theme oft kocht,

I believe that Tina oflen cooks

Similar to Ilajicoviá of al.'s (1293) suggestion for linglish, and to Matsubara el al.'s (1993) for Japanese, the last conslituent of the sentence will be recognised as rhematic, as rhemes lend to occur sentence-finally (cl. 5a and (6b). Our approach differs from Hajičcoví ct al.'s, however, in that we probibit some elements from being rhematic. In German, these inherently non-rhemalic elements include personal pronouns, as well as a limited set of modifiers such as woht in 12. Although some modifier groups tend to be potential rhemes, and others do not, most modifiers must be coded individually in the dictionary (Stcinberger, 1994). Note that if inherently nonrhematic elements occur sentence-finally, it is 
likely that cither the verb in V2 position, or the Vorfeld elcment carry heavy stress (12a vs. 12b).

12a Ir LAS+jocts den Artikel über Wortstellung dann wohl-rheme.

We read the article on word-order then presumably

12b ?? Er las den ArTtkel ïber Wortstellung dann wohl-rhense.

Hajičová et al. (1993) suggest that verbs are generally marked as rhemes, except if they have very general lexical meaning (such as be, have, happen, carry out, become). As our main concern is word order, and German verb placement is restricted by rules which do not allow variation, our algorithm does not allow the recognition of verbs as rhemes. In 12 , no constituent would be recognised as being thematic.

Not all languages express theme, rheme and focus as distinetly by word order variation as German docs. Wither they rely on the context to find out which constituents (have to) carry stress, or they use other means such as clefting, pseudo-clefting, topicalisation, dislocation, voice, impersonal constructions, particles, and morphological as woll as lexical means (Foley/Van Valin 1985). However, even in Finglish, which is often referred to as a fixed word order language, information on theme and rheme can be extracted automatically (Hajičová et. al. 1903; Steinberger 1992a). To which degree this information is conveyed in other languages, and by which means, must be subject to a language pairspecific investigation. The extraction of information on theme, rheme and focus is more important when transtating from one free phrase order language into another, than when translating into a fixed-word order language. However, there are independent reasons for recognising the sentence focus, namely the correlation between stress on the one hand, and scope of negation (Payne 1985) and of degrec modifiers (Steinberger 1992b) on the other.

\section{Ambiguity Resolution}

Findings on natural, less natural and ungrammatical word order variations can also be used to improve sentence analysis with respect to some cases of ambiguity resolution. In the case of 13 , eher can be recognised as denoting carlier (cher 26 ), as the homonymous adverb ( cher $_{5}$, "rather") must not be negated. Furthermore, some cases of unlikely PP attachment can be nearly excluded. In 14, the PP expressing location (vor (ler Jank) is unlikely to be a sentence modifier, as this would result in contrastive focussing of the personal pronoun ithn. 'This can be seen in 15 , where the PP cannot be an adjunct to the preceding $N P$, because the NP is realised as a pronoun. The $\mathrm{PP}$ in 14 is thus more likely to be an adjunct to the nominalive NP der Mann (14a) than a sentence modifier $(14 \mathrm{~b})$. The general principle is that focussing constructions are relatively unlikely to occur in written text, and therefore one should avoid the analysis involving focus when another analysis is possible. 'This is the case when the analysis of the PP as an adjunct results in a sentence without contrastive stress.

13a Er sollte nicht elser.2 kommen. (not earlier) He should not earlier come (He should not come. earlier)

$13 \mathrm{~b}$ * Fr sollte nicht eher, kommen. (rather) the should not rather come

14 Deshalb hat der Mann vor der Bank ihn gesehen. Therfore has the man in-front-of the bank him scen (Therefore the man in fronl of the bank has seen him)

l. Aa Deshalb hat der Mann vor der Bank ilun gesehen.

14b? Deshalb hat der Mann vor der Bank lnN ignoriert.

15 ?? Deshalb hat er vor der Bank IIIN geselien. Therefore has he in-front-of the bank him seen

\section{Conclusion}

The order of constituents in free phrase order languages is retermined by a set of factors which constitute tendencies rather than clear-cut rules. The fact that most, but not all, constituent orders are possible, and that some 
orders are more natural than others poses a considerable problem for NIP.

In this paper, we presented a method to deal with these problems from the analysis and the generation point of view. Concerning analysis, the main idea is that single sentences reflect, the theme-rheme structure imposed by the contexl, so that thematic, rhematic and (contrastively) focussed constituents can oftem be recognised. In generation, we can convey this knowledge by differing word order depending on the context. This is achieved by using a canonical form which includes the flexible catcgories theme, rheme and conlrastive focus.

$\Lambda$ major advantage over methods suggested in the past is that acceptability differences between sentences can be dealt with, ancl that even modifier sequences, which are tratditionally left out in word order description, can be handled. Wrong constituent orders are avoided, because the order of the major part of the sentence is fixed, and only single constituents move to the theme and rheme positions. The dificulty arising from the unclear borderline between free and fixed phrase order, which is typical of most. free phrase order languages, is dealt with successfully.

\section{Bibliography}

Comlon, Sumali Pin-Ngern and Martha Evens (1992). Can Computers Ilandle Adverbs?. In: Coling Proceedings, 1192-1196, Nantes

Engel, Uhrich (1970). Regeln zur Wortstellung. In: forschungsberichte des Instiluts für deutsche Sprache 5, 7-148, Mannheirn

Engelkamp, Judith, Gregor Erbach and IIans Us\%koreit (1992). Ilandling linear Precedence Constraints by Unification. In: ACL Proceedings, 201-208, Newark

Erbach, Gregor (1993). Using Preference Viltues in Typed Feature Structures to Fixploit Non- $\Lambda$ bsolute Const,raints for Disambiguation, In: Marald 'Trost (lid.), 173-186

Foley and Van Valin (1985). Information Packatsing in the Clause. In: 'T'imollyy Shopen (Ed.), 282-364

Hajičová, Eva, Petre Sgall and IIama Skommaloví (1993). Identifying 'lopic and Focus by an Automatic Procedure. FACI Proceedings, 178-182, Utrech
Ioberer, Ursula (1981). Die Wortstellyng in der geschriebenen deutschen Gegenwartssprache, München

Jacolbs, Joachim (1988). Trobleme der freien Wortstellung im Deutschen. In: Sprocke und Pragmatik Arbeitsterichle, 8-37, Lund

Matsubama, Tsutomu, Midetoshi Nagai, Trigo Nakamura and Mirosato Nomura (1993). Stochastic Model for locus and its Application to Dialogue Generation. In: NhPLS proceedings, 402-405, linkuoka

Pranne, Johm R. (1985). Negation. In: Tinolhy shopen (bd.), 197-212

Schäufele, Steven (1991). A Note on the 'lem 'Scrambling'. Jn: Nalural banguage and linguistic theory, volume $9.2, \quad 365-368$, Dor drecht/Boston/London

Sharp, Randall (1989). CAT'2 - A Formalism for Multilingual Machine Translation. Procedings of the International Seminar on Machine Translation, 'Tblisi, Georgia (USSIR)

Shopen, 'Iimothy (Ed.) (1985). Langnage 'l'ypology and Syntaclic Description, Volmme 1: Clause Structure, Combridge

Stcinborger, Ralf (1992a). Beschreibung der Adverbstellung im deutschen und englischen Sat: im llinblick auf Maschinelle Übersetzung. Furotra-D Working Papers No. 23, [A], Suarbrïcken

Steinberger, Ralf (1992b). Der Skopus von (irad. partikeln: Seine Übersetzung und seine Implemen tierung im Maschinclen Übersetyungssystem CN'2. Surotr(t-1) Working Papers No, 24, IAI, Satarbrïcken

Stciuberger, Ralf (1994). A Study of Word Order Variation in German, with Special Reference to Modifier Placement. PhD 'Thesis, University of Manchester

'Ihumair, Maria (1989). Modalpartikeln und ihre Kombinationen, 'Tiblingen

Trost, Ifarald (Ed.) (1993). Feature Pormalisms and Linguislic Anbiguty, Chichestep'

Uszkoneit, IIans (1987). Worl order and constituent structure in Germat. CSt/ Lecture Notes No. 8. Stanford 